\title{
Perkembangan ukuran utama kapal pukat cincin di Sulawesi Utara
}

\author{
The changing of principal dimensions of purse seiner in North Sulawesi
}

\author{
PATRICE N.I. KALANGI
}

Program Studi Pemanfaatan Sumberdaya Perikanan, Fakultas Perikanan dan Ilmu Kelautan, Universitas Sam Ratulangi, Manado 95115

\begin{abstract}
Purse seine fisheries in North Sulawesi significantly contribute to the total fisheries production in the region. The continuing increase of demand in fishery production arouses the purse seine entrepreneurs to increase their fishing power indicated by the increasing size of their fishing boats. Analyses of the principal dimensions of purse seiners have been done by many researchers, but the results tend to be quite diverse make it difficult to be used to represent the real condition. This article analyses the relationship among principal dimensions of purse seiners reported over more than a 20 years period by many researchers. The ratios of purse seiner principal dimensions in North Sulawesi are $\mathrm{L} / \mathrm{B}=4,67, \mathrm{~L} / \mathrm{D}=12,98$, and $\mathrm{B} / \mathrm{D}=2,82$; and the length of purse seiner increases in average from around $15 \mathrm{~m}$ in the beginning of the period to around $20 \mathrm{~m}$ at the end of the period.
\end{abstract}

Keywords: principal dimension, purse seiner, round scad, North Sulawesi

\begin{abstract}
ABSTRAK
Perikanan pukat cincin di Sulawesi Utara memberikan kontribusi yang besar terhadap produksi perikanan daerah. Permintaan yang terus meningkat mendorong pengusaha pukat cincin untuk terus meningkatkan kemampuan tangkap mereka yang ditandai dengan peningkatan ukuran kapal penangkap. Analisis ukuran utama kapal pukat cincin telah banyak dilakukan, tetapi cenderung memberikan hasil yang cukup berbeda sehingga sulit digunakan untuk menggambarkan kondisi sebenarnya. Artikel ini menganalis hubungan antar ukuran utama kapal pukat cincin yang dilaporkan sepanjang periode lebih dari 20 tahun oleh banyak peneliti. Rasio ukuran utama pukat cincin di Sulawesi Utara adalah $\mathrm{L} / \mathrm{B}=4,67, \mathrm{~L} / \mathrm{D}=12,98$, dan $\mathrm{B} / \mathrm{D}=2,82$; dan ukuran panjang kapal meningkat secara ratarata dari sekitar $15 \mathrm{~m}$ di awal periode menjadi sekitar $20 \mathrm{~m}$ di akhir periode.
\end{abstract}

Kata-kata kunci: ukuran utama, kapal pukat cincin, malalugis, Sulawesi Utara

\section{PENDAHULUAN}

Di Sulawesi Utara, pukat cincin yang oleh masyarakat lokal disebut pajeko umumnya digunakan untuk menangkap ikan layang (Decapterus sp.). Pada tahun 2013 produksi ikan layang di Sulawesi Utara mencapai 93.362 ton yang berkontribusi sebesar $36 \%$ dari total produksi perikanan Sulawesi Utara (DKP Prov. Sulut, 2013).

Menurut Besweni dkk. (2011), potensi perikanan pelagis kecil di wilayah pengelolaan perikanan (WPP) sekitar Sulawesi Utara yakni WPP 715 dan 716 masing-masing sebesar 379.400 dan 230.900 ton per tahun. Potensi ini dimanfaatkan

*Email: patrice.kalangi@unsrat.ac.id secara bersama dengan beberapa provinsi di WPP berkenaan, antara lain Gorontalo dan Maluku Utara. Selain itu, WPP ini juga dimanfaatkan oleh nelayan-nelayan asing baik secara legal maupun secara ilegal (Dahuri, 2012). Khususnya ikan layang, total produksi di kedua WPP ini pada tahun 2010 sebesar 100 ton (Besweni dkk., 2011).

Upaya penguasaan wilayah perairan oleh bangsa sendiri dan upaya pemenuhan permintaan pasar akan ikan layang mendorong nelayan pukat cincin untuk terus meningkatkan kemampuan tangkap. Peningkatan kemampuan ini dilakukan antara lain dengan menambah dan/atau memperbesar unit penangkapan, khususnya kapal penangkap. 
Dalam merancang sebuah kapal, ukuran utama kapal yang mencakup panjang (L), lebar (B), dan dalam (D) merupakan hal yang perlu ditentukan terlebih dahulu. Ketika panjang kapal telah ditetapkan, ukuran lebar dan dalam dapat ditentukan dengan menggunakan nilai rasio ukuran utama untuk jenis kapal yang berkenaan. Besar rasio ini akan berpengaruh terhadap kecepatan, kekuatan memanjang kapal, dan stabilitas kapal (Ayodhyoa, 1972). Selanjutnya dijelaskan pula bahwa nilai L/B yang kecil akan berpengaruh buruk terhadap kecepatan, nilai L/D yang besar akan melemahkan kekuatan memanjang kapal, dan nilai B/D yang besar akan meningkatkan stabilitas tapi menyulitkan pergerakan maju.

Hubungan antar ukuran utama kapal dapat juga diperoleh dengan analisis regresi (Huwae et al., 2010; Kalangi, 1989; Kalangi, 1993; Lungari, 2011). Untuk koefisien kemiringan garis regresi antara panjang dan lebar kapal pukat cincin, misalnya, Huwae dkk. (2010) mendapatkan $b=0,11$, sedangkan Agu (1995) dan Labobar (1995) mendapatkan nilai yang lebih kecil $b=0,07$. Perbedaan ini menimbulkan pertanyaan apakah ada perubahan ukuran dan hubungan antar ukuran utama kapal dari tahun ke tahun.

Artikel ini akan menampilkan hasil regresi dan rasio ukuran utama serta kecenderungan pertambahan ukuran kapal pukat cincin di Sulawesi Utara pada periode 1979 sampai 2011. Dengan menganalisis data pada periode yang panjang, diharap- kan akan didapatkan nilai rasio yang lebih realistis.

\section{METODE PENELITIAN}

Penelitian ini menggunakan data perikanan pukat cincin yang tersedia di Fakultas Perikanan dan Ilmu Kelautan Universitas Sam Ratulangi Manado. Ukuran utama kapal yang mencakup panjang keseluruhan, lebar, dan dalam kapal dikutip dari makalah seminar, laporan praktek kerja/ketrampilan lapang(an), skripsi dan tesis (Tabel 1).

Data ukuran utama kemudian dipetakan menurut tahun dan dibuat persamaan regresinya. Pemetaan dilakukan untuk semua jenis kapal pukat cincin yang meliputi tipe pamo, pelang (berkatir) dan kapal latih, tetapi dalam analisis regresi dan korelasi, data tiga kapal pelang (Pelealu, 1991) dan satu kapal latih (Reppie, 1981) dianggap sebagai data pencilan sehingga tidak digunakan. Kapal pukat cincin tipe pamo yang digunakan dalam penelitian ini terbuat dari kayu.

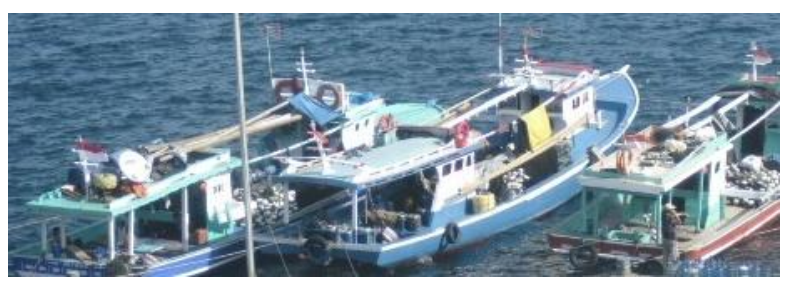

Gambar 1. Kapal cincin di Pelabuhan Perikanan Samudera Bitung

Tabel 1. Sumber data dan jumlah kapal pukat cincin yang diteliti

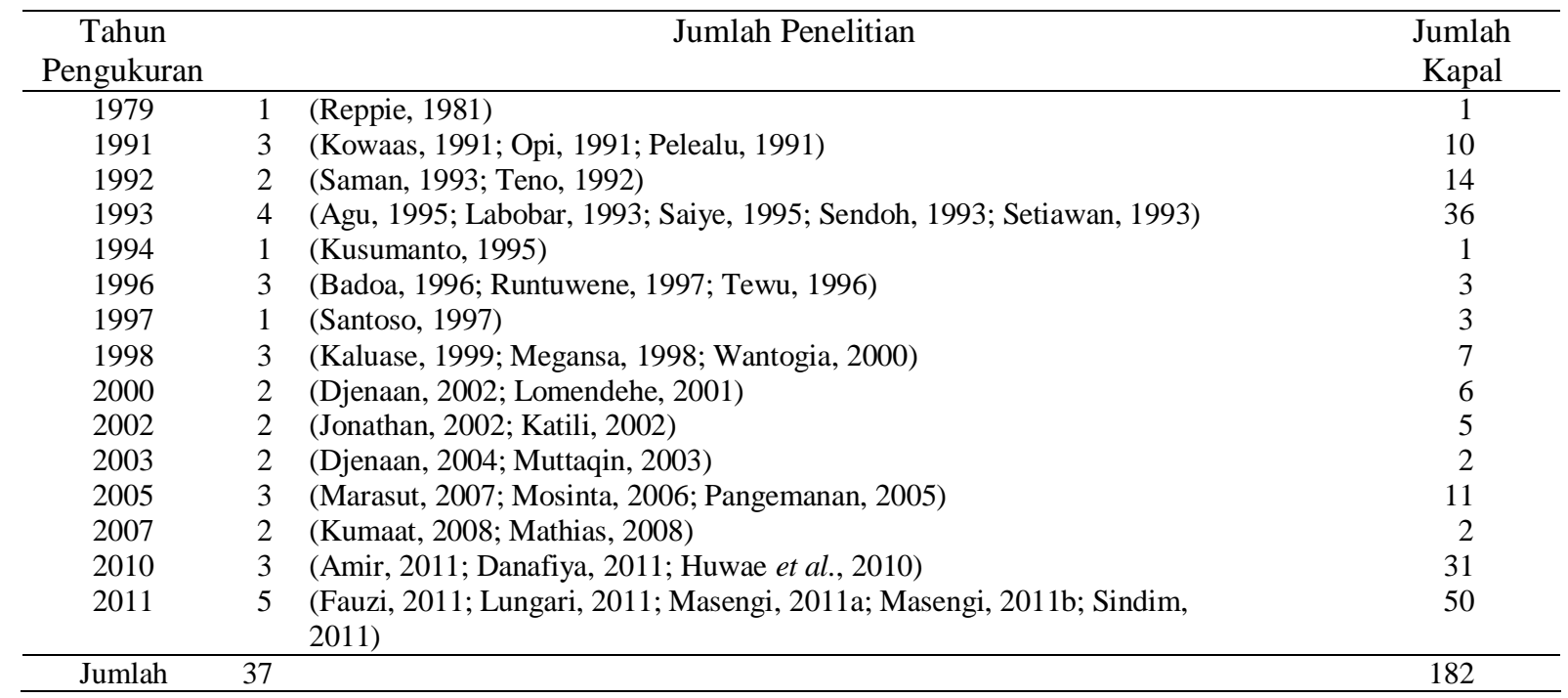




\section{HASIL DAN PEMBAHASAN}

\section{Hubungan antar ukuran utama perahu}

Perikanan pukat cincin di Sulawesi Utara dioperasikan oleh usaha perikanan dalam berbagai skala, dari skala usaha nelayan konvensional sampai skala usaha industri. Hal ini tergambar dalam ukuran kapal yang digunakan. Skala usaha nelayan konvensional dengan modal yang terbatas umumnya mengoperasikan kapal-kapal yang berukuran kecil sedangkan skala usaha dengan modal yang cukup mengoperasikan kapal-kapal yang berukuran besar. Ukuran kapal pukat cincin berkisar antara 11 dan $30 \mathrm{~m}$ untuk panjang, 1,4 dan 6,1 m untuk lebar, dan 0,75 dan 2,73 m untuk dalam.
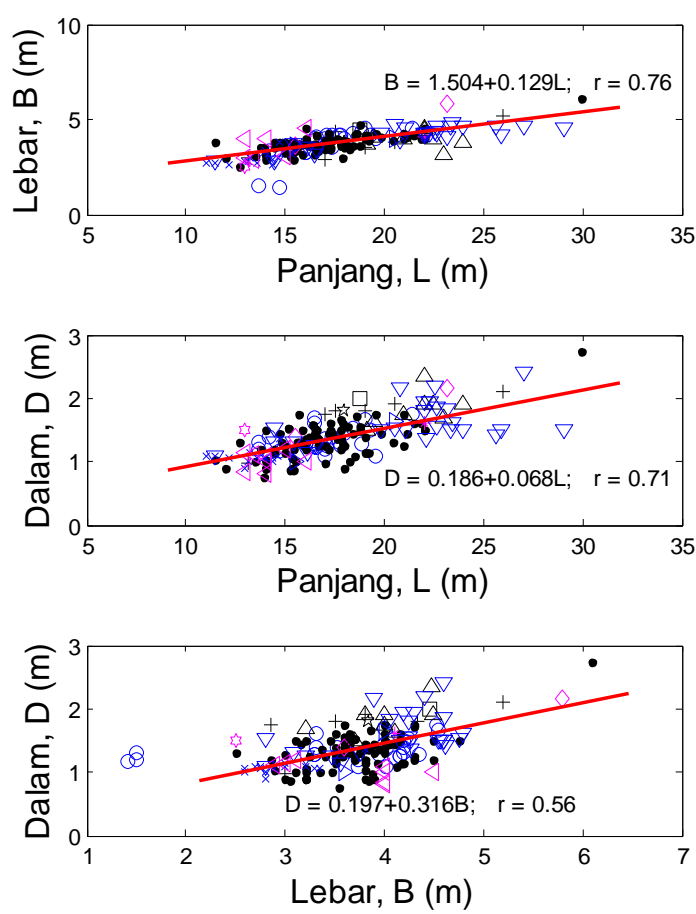

Gambar 2. Hubungan antara panjang dan lebar kapal (panel atas), antara panjang dan lebar kapal (panel tengah), dan antara lebar dan dalam kapal (panel bawah)

Gambar 2 memperlihatkan hubungan antar ukuran utama kapal yang positif, yakni pertambahan ukuran suatu dimensi akan diikuti dengan pertambahan dimensi lainnya. Nilai koefisien kemiringan garis regresi $(b)$ menunjuk pada besar nilai perubahan peubah tak bebas (sumbu $y$ ) pada setiap perubahan satu satuan pada peubah bebas (sumbu $x$ ). Koefisien kemiringan garis regresi pada hubungan antara panjang dan lebar $(b=$ $0,129)$ lebih besar dibanding pada hubungan antara panjang dan dalam kapal $(b=0,068)$. Hal ini mengartikan bahwa ukuran lebar kapal berubah lebih cepat dibanding dengan ukuran dalam kapal pada setiap perubahan ukuran panjang kapal.

Besar koefisien kemiringan garis regresi ini tidak berbeda jauh dengan hasil yang didapatkan oleh Huwae dkk. (2010) untuk 15 kapal pukat cincin. Mereka mendapatkan koefisien kemiringan untuk hubungan L-B dan L-D berturut-turut adalah 0,11 dan 0,07. Akan tetapi nilai hasil penelitian ini jauh lebih besar dibanding dengan koefisien yang diberikan oleh Labobar (1995), yakni 0,07 untuk hubungan L-B dan 0,03 untuk hubungan L-D. Perbedaan ini dapat disebabkan oleh perbedaan sampel kapal yang diukur. Namun demikian, ketika sampel yang ekstrem digabungkan dengan sampel-sampel yang lain, maka akan diperoleh nilai yang lebih mewakili.

Pertambahan lebar dan dalam sebagai fungsi dari panjang pada kapal pukat cincin mirip dengan pertambahan pada kapal funae (kapal huhate tipe pamo). Koefisien kemiringan garis regresi kapal funae untuk hubungan L-B adalah 0,12 dan untuk hubungan L-D adalah 0,04 (Kalangi, 1993).

\section{Perubahan ukuran panjang kapal menurut ta- hun}

Gambar 3 memperlihatkan ukuran panjang kapal pukat cincin mulai tahun pengukuran 1979 sampai 2011. Panjang kapal cenderung bertambah dari tahun ke tahun walaupun tingkat pertambahannya sangat kecil $(b=0,161)$ dan korelasinya agak rendah $(r=0,37)$. Di awal periode, panjang kapal sekitar $12 \mathrm{~m}$, tetapi di akhir periode panjang kapal mencapai rata-rata $20 \mathrm{~m}$. Pertambahan ini dapat menunjukkan bahwa ada upaya nelayan untuk memperbesar usaha dengan menambah ukuran kapal.

Memperhatikan Gbr. 3, variasi ukuran panjang kapal pada tahun-tahun terakhir sangat lebar (12$30 \mathrm{~m})$. Hal ini dapat menggambarkan expansivitas dari usaha perikanan di Sulawesi Utara. Ukuran yang besar memungkinkan kapal untuk mencapai daerah penangkapan ikan yang lebih jauh selain kapasitas muat yang lebih besar (Amir, 2011; Fauzi, 2011). Tetapi kapal-kapal kecil juga masih banyak ditemukan. Hal ini mengindikasikan bahwa usaha penangkapan di sekitar pantai dengan satu malam trip penangkapan masih banyak dipraktikkan oleh nelayan (Amir, 2011). 


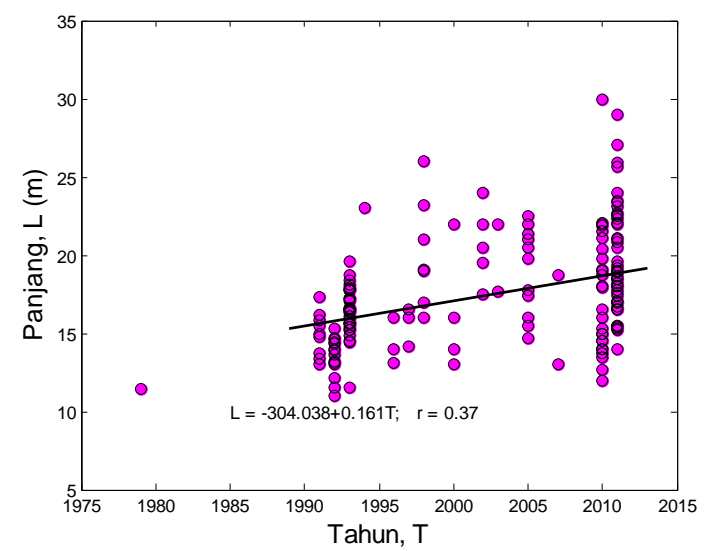

Gambar 3. Panjang kapal dari tahun ke tahun

\section{Rasio ukuran utama}

Selain dengan persamaan regresi, penentuan suatu ukuran utama lain dapat dilakukan dengan menggunakan rasio. Sesungguhnya rasio adalah invers dari koefisien kemiringan garis regresi ketika intersep $a=0$. Untuk keperluan praktis rasio lebih mudah digunakan.

Rasio ukuran utama kapal pukat cincin di Sulawesi Utara sangat bervariasi. Kisaran nilai L/B, L/D, dan B/D berturut-turut adalah 3,01$10,39,8,67-20,00$, dan $1,15-5,00$; dan nilai ratarata berturut-turut adalah 4,67, 12,98, dan 2,82. Secara keseluruhan nilai-nilai ini lebih besar dibandingkan dengan nilai yang dikemukakan oleh (Nomura and Yamazaki, 1977). Hal ini mengartikan bahwa kapal pukat cincin di Sulawesi Utara secara rata-rata lebih langsing dan lebih rendah untuk ukuran panjang yang sama, atau lebih panjang untuk ukuran lebar atau dalam yang sama. Perbedaan ini mungkin disebabkan oleh perbedaan pengetahuan dalam membangun kapal maupun perbedaan kondisi daerah penangkapan dan teknik operasi penangkapan ikan.

Rasio ukuran utama kapal pukat cincin tidak secara konsisten menunjukkan adanya perubahan dari tahun ke tahun (Gbr. 4). Peningkatan yang jelas terlihat hanya pada rasio panjang terhadap dalam kapal. Kapal pukat cincin pada tahun-tahun terakhir cenderung lebih rendah untuk panjang yang sama, atau lebih panjang untuk dalam yang sama. Kapal-kapal demikian mempunyai kemampuan lebih baik dalam menghadapi gelombang dan memiliki stabilitas yang lebih baik sehingga kenyamanan kerja lebih terjamin (Ayodhyoa, 1972).

Material kapal dapat juga mempengaruhi rasio ukuran utama kapal. Kantu dkk. (2013) melapor- kan rasio ukuran utama kapal pukat cincin yang terbuat dari fiberglass dengan panjang $20,40 \mathrm{~m}$ sebagai berikut: $\mathrm{L} / \mathrm{B}=4,7, \mathrm{~L} / \mathrm{D}=7,03, \mathrm{~B} / \mathrm{D}=$ 1,48. Kapal pukat cincin fibreglass ini memiliki bentuk yang lebih tinggi.

Dibandingkan dengan kapal funae, kapal pukat cincin berbentuk lebih lebar dan tinggi. Hal ini sebagai konsekwensi dari metode yang berbeda. Kapal pukat cincin membutuhkan stabilitas yang tinggi terutama saat penarikan dan pengangkatan jaring, sedangkan kapal funae membutuhkan kecepatan tinggi dalam mengejar gerombolan ikan dan membutuhkan bak umpan hidup. Nilai perbandingan antar ukuran utama kapal funae adalah $\mathrm{L} / \mathrm{B}=5,32, \mathrm{~L} / \mathrm{D}=12,09$, dan $\mathrm{B} / \mathrm{D}=2,28$ (Kalangi, 1993).
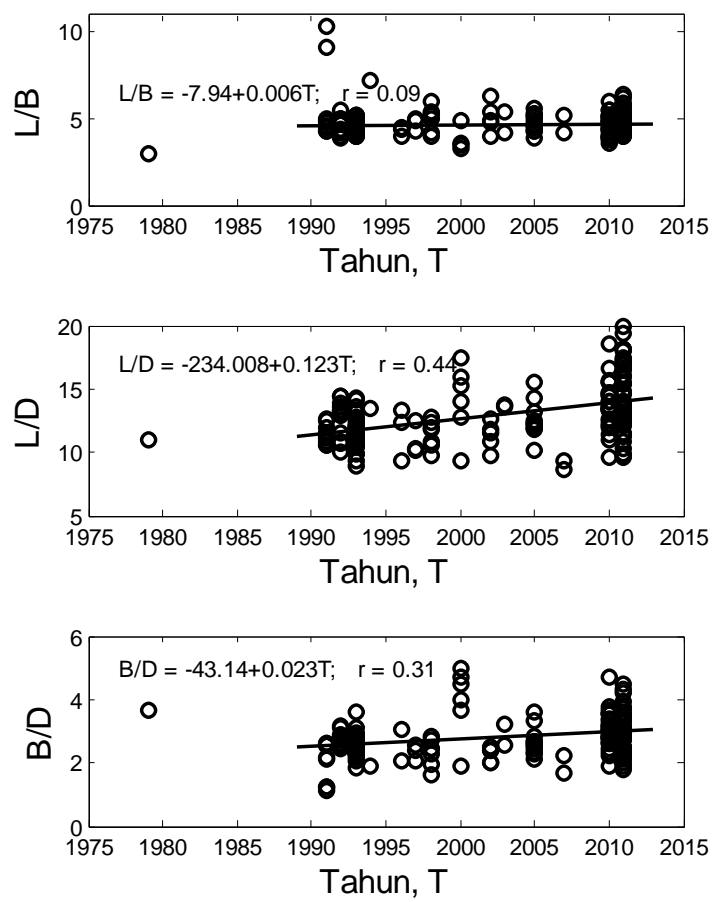

Gambar 4. Rasio ukuran utama kapal dari tahun ke tahun

Gambar 5 memberikan hubungan antara pembilang dari rasio ukuran utama kapal dengan deviasi rasio yang berkenaan. Secara umum L/D sangat bervariasi pada semua ukuran panjang kapal, sedangkan L/B lebih konsisten, kecuali untuk data pencilan. Kenyataan ini mengindikasikan bahwa pembuat dan/atau pengguna kapal pukat cincin lebih memperhatikan kesesuaian ukuran panjang dan lebar. 
Hal menarik lainnya ditunjukkan oleh hubungan antara panjang kapal dan deviasi L/B (Gbr. 5 panel atas). Sampai pada ukuran panjang kapal sekitar $20 \mathrm{~m}$, sebagian besar nilai deviasi L/B bernilai negatif atau berada di bawah nilai ratarata. Sedangkan untuk kapal-kapal yang berukuran panjang lebih besar dari $20 \mathrm{~m}$ umumnya memiliki nilai L/B di atas nilai rata-rata. Nilai yang berada di bawah rata-rata berarti kapal lebih gemuk dan tinggi, sedangkan nilai yang berada di atas ratarata berarti kapal lebih langsing dan rendah. Deviasi L/B berdasarkan panjang ini sejalan dengan pengkategorian yang diberikan oleh Nomura dan Yamazaki (1977), bahwa untuk kapal pukat cincin dengan panjang lebih kecil dari $22 \mathrm{~m}$ nilai $\mathrm{L} / \mathrm{B}$ adalah 4,3 , sedangkan untuk kapal yang lebih panjang dari $22 \mathrm{~m}$ nilai $\mathrm{L} / \mathrm{B}$ adalah 4,5. Rasio yang lain tidak menunjukkan kecenderungan yang jelas.
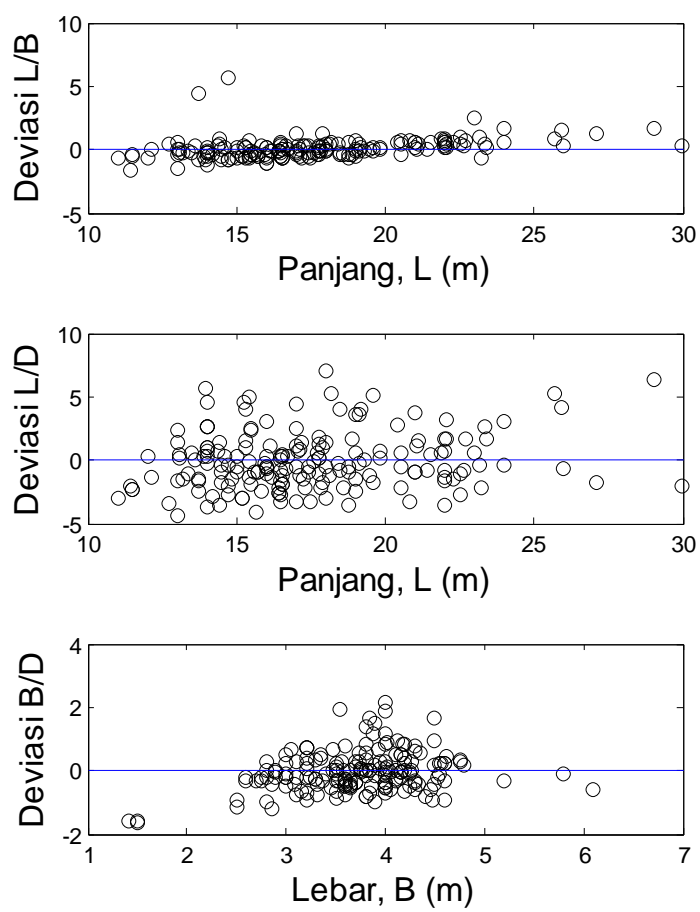

Gambar 5. Deviasi dari nilai rata-rata setiap rasio ukuran utama kapal

\section{KESIMPULAN}

Kapal pukat cincin di Sulawesi Utara dari tahun ke tahun terus bertambah panjang. Pada akhir 1980an ukuran panjang kapal sekitar $15 \mathrm{~m}$ tetapi pada tahun 2010 meningkat menjadi rata-rata sekitar 20 $\mathrm{m}$ dengan tingkat variasi yang sangat besar. Per- tambahan ukuran lebar dan dalam kapal berturutturut sebesar 0,129 dan 0,068 kali perubahan panjang kapal. Sedangkan nilai rasio antar ukuran utama kapal pukat cincin adalah $\mathrm{L} / \mathrm{B}=4,67, \mathrm{~L} / \mathrm{D}=$ 12,98 , dan $\mathrm{B} / \mathrm{D}=2,82$.

\section{DAFTAR PUSTAKA}

Agu, J.J. 1995. Studi tentang karakteristik teknis kapal pukat cincin di Kotamadya Bitung. Skripsi. Program Studi Pemanfaatan Sumberdaya Perikanan, Fakultas Perikanan, Universitas Sam Ratulangi, Manado.

Amir, I. 2011. Analisis lama operasi beberapa kapal pukat cincin ukurang kurang dari 30 GT yang berpangkalan di Pelabuhan Perikanan Samudera Bitung Sulawesi Utara. Skripsi. Program Studi Pemanfaatan Sumberdaya Perikanan, Fakultas Perikanan dan Ilmu Kelautan, Universitas Sam Ratulangi, Manado.

Ayodhyoa. 1972. Craft and Gear. Correspondence Course Centre, Jakarta.

Badoa, N. 1996. Studi tentang efisiensi teknis pukat cincin desain baru di perairan Bitung. Skripsi. Program Studi Pemanfaatan Sumberdaya Perikanan, Fakultas Perikanan, Universitas Sam Ratulangi, Manado.

Besweni, D.S. Effndi, R. Agustineke, Nugroho, G.D. Nugroho, A.W. Susilo, dan Suhadi (Editors). 2011. Peta Keragaan Perikanan Tangkap di Wilayah Pengelolaan Perikanan Republik Indonesia (WPP-RI). Direktorat Sumberdaya Ikan, Direktorat Jenderal Perikanan Tangkap, Kementerian Kelautan dan Perikanan, Jakarta.

Dahuri, R. 2012. Wilayah Perbatasan, Anatomi Pencurian Ikan di Perbatasan. Wilayah Perbatasan.com. http://www.wilayahperbatasan.com/wilayah-perbatasananatomi-pencurian-ikan-di-perbatasan/ (diakses tanggal 28 Oktober 2013).

Danafiya, A. 2011. Teknologi penangkapan ikan cakalang dengan alat tangkap pukat cincin di Laut Banda. Skripsi. Program Studi Pemanfaatan Sumberdaya Perikanan, Fakultas Perikanan dan Ilmu Kelautan, Universitas Sam Ratulangi, Manado.

Djenaan, I. 2002. Pembuatan purse seiner di Desa Buntalo Kecamatan Lolak Kabupaten Bolaang Mongondow. Laporan Praktek Ketrampilan Lapang. Program Studi Pemanfaatan Sumberdaya Perikanan, Fakultas Perikanan dan Ilmu Kelautan, Universitas Sam Ratulangi, Manado.

Djenaan, I. 2004. Studi efisiensi daya mesin terhadap kecepatan purse seiner. Skripsi. Program Studi Pemanfaatan Sumberdaya Perikanan, Fakultas Perikanan dan Ilmu Kelautan, Universitas Sam Ratulangi, Manado.

DKP Prov. Sulut. 2013. Statistik DKP Provinsi Sulawesi Utara. Dinas Kelautan dan Perikanan Provinsi Sulawesi Utara, Manado.

Fauzi, S.O. 2011. Efisiensi teknis penangkapan ikan dengan pukat cincin KM Haleluya 01 di Laut Sulawesi. Skripsi. Program Studi Pemanfaatan Sumberdaya Perikanan, Fakultas Perikanan dan Ilmu Kelautan, Universitas Sam Ratulangi, Manado.

Huwae, J.C., W.K. Sanjaya, J. Manohas, H. Rumopa, A. Tahir, T. Supit, dan S. Mokoginta. 2010. Pengukuran dan analisis perbandingan ukuran dimensi kapal mini purse seine di Pelabuhan Perikanan Samudera Bitung. Program Pascasarjana, Universitas Sam Ratulangi, Manado. 
Jonathan, A. 2002. Studi perbandingan koefisien bentuk small purse seiner di pesisir pantai utara Sulawesi Utara. Skripsi. Program Studi Pemanfaatan Sumberdaya Perikanan, Fakultas Perikanan dan Ilmu Kelautan, Universitas Sam Ratulangi, Manado.

Kalangi, P.N.I. 1989. Analisis beberapa karakter teknis perahu pelang bermotor di pesisir pantai Kecamatan Belang Kabupaten Minahasa Propinsi Sulawesi Utara. Tesis. Program Studi Pemanfaatan Sumberdaya Perikanan, Fakultas Perikanan, Universitas Sam Ratulangi, Manado.

Kalangi, P.N.I. 1993. Ukuran utama dan disain kapal funae. Fakultas Perikanan, Universitas Sam Ratulangi, Manado.

Kaluase, D. 1999. Studi perbandingan efisiensi teknis pukat cincin Metropolitan dan pukat cincin Karunia 07 di Sulawesi Utara. Skripsi. Program Studi Pemanfaatan Sumberdaya Perikanan, Fakultas Perikanan dan Ilmu Kelautan, Universitas Sam Ratulangi, Manado.

Kantu, L., P.N.I. Kalangi, dan J.F. Polii. 2013. Desain dan parameter hidrostatis kasko kapal fiberglass tipe pukat cincin 30 GT di galangan kapal CV Cipta Bahari Nusantara Minahasa Sulawesi Utara. Jurnal Ilmu dan Teknologi Perikanan Tangkap 1(3): 81-86.

Katili, S.R. 2002. Studi perbandingan stabilitas model kapal pukat cincin yang menggunakan sayap dan bentuk standar. Skripsi. Program Studi Pemanfaatan Sumberdaya Perikanan, Fakultas Perikanan dan Ilmu Kelautan, Universitas Sam Ratulangi, Manado.

Kowaas, B.A. 1991. Studi perbandingan tentang efisiensi teknis penangkapan pukat cincin yang beroperasi di perairan Batu Putih dan perairan sekitar Manado Propinsi Sulawesi Utara. Skripsi. Program Studi Pemanfaatan Sumberdaya Perikanan, Fakultas Perikanan, Universitas Sam Ratulangi, Manado.

Kumaat, S. 2008. Kajian pemakaian bahan bakar minyak kapal fibreglass jenis purse seine "KM Maestro" di perairan Desa Likupang Kabupaten Minahasa Utara. Skripsi. Program Studi Pemanfaatan Sumberdaya Perikanan, Fakultas Perikanan dan Ilmu Kelautan, Universitas Sam Ratulangi, Manado.

Kusumanto, A. 1995. Studi efisiensi teknis soma pajeko desain nelayan tradisional di peraira Lolak. Skripsi. Program Studi Pemanfaatan Sumberdaya Perikanan, Fakultas Perikanan, Universitas Sam Ratulangi, Manado.

Labobar, F. 1993. Operasi penangkapan ikan belanak (Mugil cephalus) dengan jaring insang lingkar di perairan Desa Sauk Kecamatan Lolak Kabupaten Bolaang Mongondow. Laporan Praktek Ketrampilan Lapang. Program Studi Pemanfaatan Sumberdaya Perikanan, Fakultas Perikanan, Universitas Sam Ratulangi, Manado.

Labobar, F. 1995. Studi perbandingan karakteristik teknis kapal purse seine buatau Siau dan Arakan yang berpangkalan di Kecamatan Bitung Tengah Kotamadya Bitung Propinsi Sulawesi Utara. Skripsi. Program Studi Pemanfaatan Sumberdaya Perikanan, Fakultas Perikanan, Universitas Sam Ratulangi, Manado.

Lomendehe, Y.D. 2001. Studi perbandingan efisiensi teknis beberapa alat penangkap ikan pukat cincin di Kelurahan Tarorane Kecamatan Siau Timur Kabupaten Sangihe Talaud. Skripsi. Program Studi Pemanfaatan Sumberdaya Perikanan, Fakultas Perikanan dan Ilmu Kelautan, Universitas Sam Ratulangi, Manado.

Lungari, F.F. 2011. Kajian kemampuan muat (Gross Tonnage) kapal pukat cincin (purse seiner) di beberapa pusat perikanan tangkap di Sulawesi Utara. Skripsi. Program Studi Pemanfaatan Sumberdaya Perikanan, Fakultas Perikanan dan Ilmu Kelautan, Universitas Sam Ratulangi, Manado.

Marasut, D.T. 2007. Analisis karakteristik teknis kapal pukat cincin (small purse seiner) pada beberapa daerah di SULUT dengan aplikasi komputer. Skripsi. Program Studi Pemanfaatan Sumberdaya Perikanan, Fakultas Perikanan dan Ilmu Kelautan, Universitas Sam Ratulangi, Manado.

Masengi, M. 2011a. Beberapa parameter yang digunakan dalam menganalisis kurva hidrostatis kapal perikanan. Makalah. Program Studi Pemanfaatan Sumberdaya Perikanan, Fakultas Perikanan dan Ilmu Kelautan, Universitas Sam Ratulangi, Manado.

Masengi, M. 2011b. Kajian kurva hidrostatis kapal pukat cincin (small purse seiner) di beberapa tempat di Sulawesi Utara. Skripsi. Program Studi Pemanfaatan Sumberdaya Perikanan, Fakultas Perikanan dan Ilmu Kelautan, Universitas Sam Ratulangi, Manado.

Mathias, Y.A. 2008. Pengoperasian mini purse seine di Desa Poigar I, Kecamatan Sinonsayang Kabupaten Minahasa Selatan. Laporan Praktek Kerja Lapang. Program Studi Pemanfaatan Sumberdaya Perikanan, Fakultas Perikanan dan Ilmu Kelautan, Universitas Sam Ratulangi, Manado.

Megansa, M.M. 1998. Studi kelajuan tenggelam dan kedalaman tali pemberat pukat cincin di Sulawesi Utara. Skripsi. Program Studi Pemanfaatan Sumberdaya Perikanan, Fakultas Perikanan dan Ilmu Kelautan, Universitas Sam Ratulangi, Manado.

Mosinta, R.N.L. 2006. Studi perbandingan efisiensi teknis dan jumlah tangkapan pukat cincin kecil Tawakal dan Camar yang beroperasi di perairan Sangihe Provinsi Sulawesi Utara. Skripsi. Program Studi Pemanfaatan Sumberdaya Perikanan, Fakultas Perikanan dan Ilmu Kelautan, Universitas Sam Ratulangi, Manado.

Muttaqin, A.R. 2003. Perbandingan hasil tangkapan soma pajeko yang menggunakan alat bantu lampu neon (TL) dengan karakteristik yang berbeda di perairan Desa Molompar Kecamatan Belang Kabupaten Minahasa Propinsi Sulawesi Utara. Skripsi. Program Studi Pemanfaatan Sumberdaya Perikanan, Fakultas Perikanan dan Ilmu Kelautan, Universitas Sam Ratulangi, Manado.

Nomura, M. dan T. Yamazaki. 1977. Fishing Techniques 1. JICA, Tokyo.

Opi, A.C. 1991. Studi perbandingan efisiensi teknis soma pajeko dan soma giop beroperasi di perairan Siau Timur Kabupaten Sangihe Talaud Propinsi Sulawesi Utara. Skripsi. Program Studi Pemanfaatan Sumberdaya Perikanan, Fakultas Perikanan, Universitas Sam Ratulangi, Manado.

Pangemanan, R. 2005. Studi tentang efisiensi teknis pukat cincin "Kaisar Laut" di perairan Molompar Kabupaten Minahasa Selatan. Skripsi. Program Studi Pemanfaatan Sumberdaya Perikanan, Fakultas Perikanan dan Ilmu Kelautan, Universitas Sam Ratulangi, Manado.

Pelealu, J. 1991. Sukses penangkapan ikan pelagis kecil dengan soma pajeko (small purse seine) di perairan Kecamatan Belang Kabupaten Minahasa Propinsi Sulawesi Utara. Laporan Praktek Ketrampilan Lapang. Program Studi Pemanfaatan Sumberdaya Perikanan, Fakultas Perikanan, Universitas Sam Ratulangi, Manado.

Reppie, E. 1981. Teknologi penangkapan ikan dengan kapal purse seine Tembang 01. Laporan Praktek Kerja Lapang. Fakultas Perikanan, Universitas Sam Ratulangi, Manado. 
Runtuwene, R.N. 1997. Keadaan umum perikanan tangkap di Desa Kapitu Kecamatan Tombasian Kabupaten Minahasa Propinsi Sulawesi Utara. Makalah. Program Studi Pemanfaatan Sumberdaya Perikanan, Fakultas Perikanan dan Ilmu Kelautan, Universitas Sam Ratulangi, Manado.

Saiye, Z. 1995. Studi tentang beberapa karakter dinamis kapal pukat cincin di Kecamatan Bitung Tengah Kotamadya Bitung. Skripsi. Program Studi Pemanfaatan Sumberdaya Perikanan, Fakultas Perikanan, Universitas Sam Ratulangi, Manado.

Saman, H. 1993. Analisis ukuran utama beberapa kapal small purse seine di Kecamatan Kota Selatan Kotamadya Gorontalo. Laporan Praktek Ketrampilan Lapang. Program Studi Pemanfaatan Sumberdaya Perikanan, Fakultas Perikanan, Universitas Sam Ratulangi, Manado.

Santoso, H. 1997. Stabilitas purse seiner di Desa Molompar Kecamatan Belang Kabupaten Minahasa Propinsi Sulawesi Utara. Skripsi. Program Studi Pemanfaatan Sumberdaya Perikanan, Fakultas Perikanan dan Ilmu Kelautan, Universitas Sam Ratulangi, Manado.

Sendoh, J.K. 1993. Efisiensi teknis penangkapan ikan pelagik kecil dengan pukat cincin Aertembaga Kotamadya Bitung Propinsi Sulawesi Utara. Skripsi. Program Studi Pemanfaatan Sumberdaya Perikanan, Fakultas Perikanan, Universitas Sam Ratulangi, Manado.

Setiawan, I.E. 1993. Studi tentang karakteristik dinamis small purse seiner di perairan Teluk Manado. Skripsi. Program
Studi Pemanfaatan Sumberdaya Perikanan, Fakultas Perikanan, Universitas Sam Ratulangi, Manado.

Sindim, F.J. 2011. Stabilitas dinamis kapal ikan tipe pajeko (small purse seiner) yang berpangkalan di Pelabuhan Perikanan Samudera (PPS) Bitung. Skripsi. Program Studi Pemanfaatan Sumberdaya Perikanan, Fakultas Perikanan dan Ilmu Kelautan, Universitas Gadjah Mada, Manado.

Teno, R.L. 1992. Studi operasi soma pajeko di Kelurahan Leato Selatan Kecamatan Kota Selatan Kotamadya Gorontalo Propinsi Sulawesi Utara. Laporan Praktek Ketrampilan Lapang. Program Studi Pemanfaatan Sumberdaya Perikanan, Fakultas Perikanan, Universitas Sam Ratulangi, Manado.

Tewu, F.F. 1996. Studi perbandingan efisiensi teknis pukat cincin desain lama dan baru di Kotamadya Bitung. Skripsi. Program Studi Pemanfaatan Sumberdaya Perikanan, Fakultas Perikanan, Universitas Sam Ratulangi, Manado.

Wantogia, I.B. 2000. Studi perbandingan tentang efisiensi teknis pukat cincin Benhur tipe Amerika dan pukat cincin Matuari tipe Jepang di perairan Amurang Kecamatan Tombasian Kabupaten Minahasa Propinsi Sulawesi Utara. Skripsi. Program Studi Pemanfaatan Sumberdaya Perikanan, Fakultas Perikanan dan Ilmu Kelautan, Universitas Sam Ratulangi, Manado. 